\title{
The Relationship between Knowledge and Income on the Diet of Postpartum Mothers in South Tapanuli Regency
}

\author{
Adelina Fitri Tanjung ${ }^{1}$, Etti Sudaryati ${ }^{2}$, Jumirah $^{3}$ \\ ${ }^{1,2,3}$ Universitas Sumatera Utara, Indonesia \\ Corresponding Author: Adelina Fitri Tanjung
}

\begin{abstract}
Diet is the regulation of the amount and type of food with a description of nutritional status. Many factors influence the diet of postpartum mothers, namely knowledge and income. This study aims to determine the relationship between knowledge and income on the diet of postpartum mothers in South Tapanuli Regency. This type of research uses quantitative research with a cross-sectional research design. The populations in this study were all postpartum mothers from 0-40 days ahead and the sample was taken by multistage random sampling so that there were 265 samples. Data were collected using interviews and 24 hours recall. The data analysis method used in this study was multivariate analysis. The results showed that there was a relationship between knowledge and diet $(\mathrm{p}<0.05)$, and there was a relationship between income and diet $(p<0.05)$. Family participation, especially husbands, is needed to support the diet of postpartum mothers, and it is hoped that the role of health workers in providing information about eating patterns during the postpartum period is expected to increase a good diet in the next postpartum period
\end{abstract}

Keywords: Knowledge, Income, Diet

\section{INTRODUCTION}

Sustainable development goals (SDGs) are sustainable development efforts that are used as references in the framework of development and negotiations of countries in the world as a substitute for the global development of the Millennium Development Goals (MDGs) which ended in 2015. Some of the SDGs objectives include ensuring a healthy life and promoting prosperity. For all people of all ages with one of the outputs reducing the maternal mortality rate (MMR) to 70 per 100,000 live births by 2030 (Kementerian Kesehatan, 2018).

Maternal and child health problems are one of the main problems in the health sector currently occurring in Indonesia. Every three minutes, somewhere in Indonesia, a minor dies due to childbirth or causes related to pregnancy. Until now, there have been many health development programs in Indonesia aimed at overcoming maternal and child health problems. Basically, these programs focus more on efforts to reduce infant and child mortality, crude birth rates and maternal mortality rates.

Indonesia is a country with high rates of maternal morbidity and mortality. Maternal mortality and morbidity are still serious health problems in developing countries. The World Health Organization (WHO) records that around eight million women per year experience complications of pregnancy and around 536,000 die, of which 99 percent occur in developing countries, including Indonesia. The maternal mortality rate due to complications of pregnancy, childbirth and childbirth in developing countries is one in 11 women, which is much higher than in developed countries, which is one in 5,000 women. 
Along with the increase in population and the number of pregnancies, childbirths, postpartum complications and risks, also influence the high morbidity and mortality of mothers. The causes of maternal morbidity and mortality are social factors, demographics, culture, characteristics, education, knowledge and access to health services. This indicator is not only able to assess maternal health programs, but also to assess the degree of public health, because of its sensitivity to improvements in health services, both in terms of accessibility and quality.

Postpartum maternal health services must be according to standards, which are carried out at least three times according to the recommended schedule, namely at six hours to three days after delivery, on the fourth to 28th day after delivery, and on the 29th day. up to 42 days after delivery. Postpartum visit coverage (KF3) in Indonesia shows an increasing trend from 2008 of 17.9 percent to 87.36 percent in 2017. The province with the highest coverage is DKI Jakarta, followed by North Kalimantan and Jambi. While the provinces with the lowest postpartum visit coverage are Papua, West Papua, and East Nusa Tenggara, and from 34 provinces of postpartum visit data, nearly 60 percent of provinces in Indonesia have reached KF3. 80 percent of these visits aim to provide education to mothers during the postpartum period (Kementerian Kesehatan, 2017).

The postpartum period of the mother requires balanced nutrition for her body needs, where nutrition during postpartum and breastfeeding increases by 25 percent, which is useful for the healing process after giving birth and the production of breast milk to meet the needs of her baby. In addition, the nutrients consumed are useful for carrying out activities, metabolism, reserves in the body. If the postpartum mother lacks nutrition, it will result in impaired growth of the baby and instability in the health of the nursing mother (Inayah, 2007).
Diet is the regulation of the amount and type of food with a description of nutritional status. Many factors influence the diet of postpartum mothers, namely knowledge and income.

In general, the factors that influence the formation of a diet in postpartum mothers are economic factors, socio-cultural factors, religious factors, educational factors, environmental factors. A good diet is in accordance with the Nutritional Adequacy Rate and has a variety of foods.

Many factors affect a person's nutritional status, including economy, education, knowledge in food processing, environment, and culture that are believed to be food intake, which causes a decrease in physical condition that triggers infectious diseases. Both of these are the direct causes of nutritional problems (Aritonang, 2006).

Various nutritional disorders can be prevented with support from the environment of the mother who gives birth, either through the behavior of parents or caregivers, by always providing food with balanced nutrition for their family members. Balanced nutrition is a variety of foods consumed by individuals in one day and contains energy, building materials, regulatory substances, etc. according to the body's needs (Mudjajanto, 2007).

Food is one of the factors that affect the production of postpartum breast milk, the addition of nutrients during breastfeeding to meet the needs of breast milk production. In general, things that must be considered in meeting the nutritional needs of nursing mothers are: balanced menu structure, it is recommended to drink 8-12 glasses per day, to facilitate digestion, avoid consuming alcohol, foods that are rich in spices, and eating lots of colored vegetables. As long as the mother does not have a disease that requires the mother to follow a certain diet, there is no dietary restriction for breastfeeding mothers (Zakaria, 2007).

Macro nutrient components consumed by breastfeeding mothers must be able to meet the needs of the mother, in 
addition to the formation of breast milk. Intake exceeds energy needs, so the mother increases body weight. Meanwhile, intake that is less than the minimum requirement will cause breastfeeding mothers to become malnourished, and it is feared that it will interfere with the breastfeeding process. Micronutrient needs such as folic acid, zinc, iodine, calcium, iron, vitamin A and vitamin B6 for breastfeeding mothers have also increased, and are expected to be met from the mother's daily food intake (Wahyuningsih, 2018).

Malnutrition in postpartum or nursing mothers causes health problems for both mother and baby. Disorders in babies who get sick easily, are prone to infections, lack of essential substances causes eye, bone and growth problems and in postpartum mothers it will slow down the healing process of perineal wounds. If the mother does not get food with balanced nutrition, it can result in the mother being malnourished and lacking blood and the mother will provide breast milk with a small amount of lack of fulfillment of postpartum nutrition or breastfeeding due to many factors, including dietary restrictions for postpartum mothers (Fitriani, 2005).

The results of research conducted by Rahmawati (2015), with a total sample of 24 people, showed that 33.3 percent of respondents had unfulfilled nutritional needs due to several things, one of which was the culture of abstinence from food for new mothers.

The proportion of malnutrition and malnutrition status in children under five from 2013-2018 has increased, from 20132018, namely 17.7 percent, increased to 19.6 percent and in North Sumatra Province, the number of malnutrition and malnutrition among toddlers was around 18.4 percent. 20.2 percent, and from the health profile of South Tapanuli from 2015-2017 there was an increase in malnutrition from 18-20 and malnutrition from 258-289, in this case it is related to maternal diet and breastfeeding, and the coverage of postpartum services in South Tapanuli District was only 92.11 percent in 2017, and there are still 7.9 percent who have not been touched by postpartum services.

South Tapanuli Regency is the result of a division consisting of 14 Districts so that from their eating habits there is no significant difference, including food for postpartum mothers, so that the preliminary survey was only carried out in the West Angkola District. This sub-district is an area that is far from the District Capital. a market that is opened once a week, this situation illustrates the limited availability of family food obtained from the market, especially in the availability of fresh fish. This causes limited consumption of vegetables and other foods, but they plant several types of vegetables in their yards or in the fields, such as sweet potato leaves, rimbang, eggplant, string beans, and jipang.

This study aims to determine the relationship between knowledge and income on the diet of postpartum mothers in South Tapanuli Regency.

\section{RESEARCH METHODS}

This type of research uses quantitative research with a cross-sectional research design. By using a cross-sectional study where data collection is done at one time or the same period in measuring the independent and dependent variables.

This research was conducted in several sub-districts in South Tapanuli Regency with an estimated time from the approval of the title to the completion of the research. The consideration in determining the location of this research is because this location has the population and sample needed by the researcher.

The populations in this study were all postpartum mothers from 0-40 days ahead and the sample was taken by multistage random sampling so that there were 265 samples.

Data were collected using interviews and 24 hours recall.

The data analysis method used in this study was multivariate analysis. Multivariate analysis was used to determine 
which variables were most associated with the postpartum diet.

\section{RESULT}

\section{Research Location Description}

South Tapanuli Regency is a district in North Sumatra, Indonesia. Its capital is Sipirok. This district was originally a very large district and had thousands of cities in Padangsidempuan. The areas that have separated from South Tapanuli Regency are Mandailing Natal, Padang Sidempuan City, North Padang Lawas and South Padang Lawas. After the expansion, the district capital moved to Sipirok.

This regency has Lake Marsabut and Danau Siais attractions. The language used by the people is the Batak Angkola language. The majority of the population is Muslim. An airport is located in Aek Godang District. The slogan of this district is Sahata Saoloan (Angkola Language) which means Seia Sekata. South Tapanuli Regency consists of 14 Districts, 37 SubDistricts, and 211 Villages with an area of $6,030.47 \mathrm{~km}^{2}$ and a population of around 303.428 people (2017) with a population density of 50 people / $\mathrm{km}$, to the north, this regency borders Tapanuli Regency. Central and North Tapanuli. In the eastern part, it is bordered by Padang Lawas and North Padang Lawas Regencies, to the West and South it is bordered by Mandailing Regency, and right in the middle of its territory, there is the city of Padangsidimpuan which is entirely surrounded by this regency.

\section{Multivariate Analysis}

In the multivariate analysis, it is known that there are two variables that are thought to have a relationship with the incidence of postpartum maternal diet, namely knowledge and income variables. The next stage, the two variables were entered as candidates for multivariate analysis.

Multivariate analysis aims to obtain the best model in determining the dominant variable that affects the incidence of postpartum maternal diet. In this modeling, all variables that have a $p$ value $<0.025$ in the bivariate analysis will be entered into the logistic regression test as in Table 1 below:

Table 1. Multivariate Analysis

\begin{tabular}{|l|c|r|r|r|r|c|}
\hline & B & S.E. & Wald & Df & Sig. & Exp(B) \\
\hline Knowledge & 0.424 & 0.118 & 3.143 & 1 & 0.024 & 1.528 \\
\hline Income & -0.367 & 0.207 & 0.231 & 1 & 0.076 & 0.693 \\
\hline Constant & -3.117 & 1.103 & 0.579 & 1 & 0.037 & 3.351 \\
\hline
\end{tabular}

Overall Percentage: $78.5 \%$

After issuing the variables with $\mathrm{p}$ value $<0.05$ gradually, one variable is included as a candidate model, namely the knowledge variable of postpartum mothers as a whole. This model can predict the magnitude of the influence of knowledge and income by $78.5 \% \quad(78.5 \%$ overall percentage) while $21.5 \%$ is influenced by other factors.

Obtained the value of the exp coefficient (B) for knowledge of 1.528 with a $p$ value of 0.024 . This means that knowledge of postpartum mothers has a 52 times chance of occurring in eating patterns.

The results too showed that there was a relationship between knowledge and diet $(\mathrm{p}<0.05)$, and there was a relationship between income and diet $(\mathrm{p}<0.05)$.

\section{CONCLUSION AND SUGGESTION}

The results showed that there was a relationship between knowledge and diet $(\mathrm{p}<0.05)$, and there was a relationship between income and diet $(\mathrm{p}<0.05)$.

Family participation, especially husbands, is needed to support the diet of postpartum mothers, and it is hoped that the role of health workers in providing information about eating patterns during the postpartum period is expected to increase a good diet in the next postpartum period 


\section{REFERENCES}

1. Aritonang, I. (2006). Krisis Ekonomi Akar Masalah Gizi. Yogyakarta: Media Pressindo.

2. Fitriani S. (2005). Gambaran Perilaku Ibu Hamil Berpantang Makanan Berdasarkan Karakteristik Ibu di Puskesmas Gondong Rejo Blitar. Fakultas Kesehatan Masyarakat, Universitas Indonesia, Depok.

3. Inayah H, K. (2007). Pengetahuan Ibu Hamil dan Nifas Tentang Tanda Bahaya Kehamilan, Persalinan, dan Masa Nifas. Banjarmasin.

4. Kementerian Kesehatan. (2017). Profil Kesehatan Indonesia Tahun 2016. Jakarta: Kementerian Kesehatan Indonesia.

5. Kementerian Kesehatan. (2018). Riset Kesehatan Dasar. Kementerian Kesehatan Republik Indonesia.

6. Muljajanto, E. S., \& Sukandar, D. (2007). Food Consumption and Nutritional Status of Breast Peeding Mother and Infants. Gizi dan Pangan, 2(2), 13-25.
7. Rahmawati, D. D. (2015). Perbedaan Persen Lemak Tubuh, Konsumsi Lemak, Karbohidrat dan Air pada Remaja Putri yang Overweight dan Tidak Overweight di Fakultas Ilmu Kesehatan UMS. Skripsi. Universitas Muhammadiyah Surakarta.

8. Wahyuningsih, Heni Puji. (2018). Bahan Ajar Kebidanan Asuhan Kebidanan Nifas dan Menyusui. Kementerian Kesehatan Republik Indonesia.

9. Zakaria, Rosmini, Famri, A. (2007). Gambaran Asupan Makanan dan Gizi Ibu Nifas Rawat Inap di Rumah Sakit Umum Daya Kota Makasar Tahun 2007. Media Gizi Pangan, 2(6), 35-38.

How to cite this article: Tanjung AF, Sudaryati E, Jumirah. The relationship between knowledge and income on the diet of postpartum mothers in South Tapanuli Regency. International Journal of Research and Review. 2021; 8(2): 49-53. 